Original Article

Artigo Original

\title{
Association of Practice of Sports in and out-of-school with Scholar Performance - Evidence from Moscow and Saint Petersburg: a Longitudinal Study
}

\section{Associação de prática de esportes dentro e fora da escola com desempenho escolar - evidências de Moscou e São Petersburgo: um estudo longitudinal}

\author{
Edgar Demetrio Tovar-García ${ }^{\S 1} \mathrm{PhD}$
}

Received: July 28, 2017. Accepted: October 6, 2017.

Published: December 19, 2017

\begin{abstract}
Introduction: It is well known the maxim mens sana in corpore sano (a sound mind in a healthy body), which suggests a positive nexus between sports and educational outcomes. However, this nexus has been empirically studied mostly in the USA, where the results are mixed, even suggesting that participation in sports may negatively influence educational outcomes.

Objective: This article empirically studies the relationship between sport activities at school and out-of-school and educational achievements of school students from 1st to 11th grade in Moscow and Saint Petersburg, Russia.

Methods: This was a longitudinal observational study, that used data from the Russia Longitudinal Monitoring Survey, annual observations covering the period 2010-2015 and 1529 observations were examined. Associations were examined using ordered probit regressions with panel data.

Results: Sport activities at school do not have statistically significant links with school grades. Conversely, sport activities out-of-school are positively associated with educational achievements. Specifically, in the case of boys, participation in ball sports increases their probabilities of having obtained

\begin{tabular}{|l|}
\hline Keypoints \\
- Participation in sports at \\
school is not associated with \\
higher school grades, most \\
probably due to the lack of \\
quality in physical education \\
classes. \\
- Conversely, the practice of \\
sports out-of-school are linked \\
to higher school grades. \\
- Furthermore, students \\
spending more hours on sports \\
will reduce their chances of \\
achieving higher school grades.
\end{tabular}
higher school grades. For girls, participation in other sports out-or-hours school increases those probabilities. However, spending more than 10 hours on sports reduces those likelihoods.

Conclusion: Parents and teachers should encourage the participation of their children in sport activities; this will benefit their educational outcomes. However, the practice of sports at school is irrelevant, indicating that policy makers should restore the quality of physical education classes.
\end{abstract}

Keywords: sport activities, educational performance, ordered probit regression, panel data.

\section{Resumo}

Introdução: 0 lema mens sana in corpore sano (mente saudável no corpo saudável) é amplamente conhecido e sugere uma conexão positiva entre os resultados do esporte e a educação. Tal conexão tem sido testada

$\S$ Corresponding Author: Edgar Demetrio Tovar-García - e-mail: etovar@up.edu.mx.

Affiliations: ${ }^{1}$ School of Economic and Administrative Sciences, Universidad Panamericana, Guadalajara, Mexico. 
empiricamente, principalmente nos Estados Unidos, mas os resultados são controversos, sendo que alguns estudos sugerem que a participação no esporte poderia ter influências negativas nos resultados educativos.

Objetivo: Examinar a relação das atividades esportivas, na escola e fora desta com os resultados escolares de estudantes do $1^{\circ}$ ao $11^{\circ}$ ano do Ensino Básico e Fundamental em Moscou e em Sam Petersburgo, Rússia.

Métodos: Estudo de observação longitudinal que utilizou dados do Rússia Longitudinal Monitoring Survey (RLMS), com observações anuais que cobriram o período de 2010-2015. Participaram do estudo 571 crianças em idade escolar e 1529 observações compuseram as análises. As correlações foram examinadas usando regressões probit com panéis de dados.

Resultados: As atividades esportivas na escola não apresentaram correlação com os resultados das notas escolares $(p>0,05)$. Por outro lado, as atividades esportivas fora da escola mostraram benefício positivo no desempenho educacional. Especificamente, no caso dos meninos, a participação nos esportes de bola aumentou a probabilidade de se obterem notas maiores na escola. Para as meninas, a participação em esportes fora da escola também favoreceu o desempenho escolar. Porem, tanto para meninas quanto para meninos, dedicar mais de 10 horas por semana aos esportes prejudica o desempenho escolar.

Conclusão: Pais e professores devem estimular a participação das crianças em atividades esportivas pois apresentam benefícios para os resultados educacionais. Porem, a prática dos esportes na escola mostrou-se irrelevante nos resultados, escolares indicando que as

Pontos-Chave Destaque

- Não houve associação de participação esportiva na escola com os melhores resultados nas notas escolares, provavelmente devido a baixa qualidade das aulas de educação física escolar.

- Porem, a prática dos esportes fora da escola tem um impacto positivo com melhores resultados nas notas escolares. - Além disso, estudantes que passam muitas horas em atividades esportivas podem ter reduzidos as chances de obter maiores notas na escola. políticas educacionais deveriam acrescentar e exigir maior qualidade das atividades físicas na escola (educação física escolar).

\section{Association of Practice of Sports in and out-of-school with Scholar Performance - Evidence from Moscow and Saint Petersburg: a Longitudinal Study}

\section{Introduction}

In the USA, many empirical studies from 60 's to the 80's found an inverse relationship between sport participation and educational outcomes(1,2). In the American context, sports are part of extracurricular school activities, and those studies observed that sports create distraction, make students too tired, nervous, or excited, blocking their attention to academic activities. In other words, sports promote higher levels of school deviance. Moreover, participation in sport school teams has been linked to the use of illicit drugs and alcohol(3). It is well known that the use of these substances may negatively affect educational outcomes, for instance, school attendance, school grades, educational aspirations, and educational attainment.

The most recent studies, on the contrary, highlight the benefits of sport activities on educational outcomes(4-6). Actually, these studies reuse arguments expressed 100 years ago by physical educators, neurologists, physicians, and psychologists(5). Sports are considered as constructive leisure activities, and they encourage biological and psychosocial factors positively influencing educational outcomes $(3,4)$. For this reason, in the majority of countries, sport activities at physical education classes are part of the school curriculum(7).

Sports offer educational experiences beyond the typical experiences at the classroom, for 
example, training and discipline to accomplish goals and strategies for adaptation to teamwork $(8,9)$. Furthermore, sports offer options to increase the students' social capital because these activities allow them the creation of new networks with trainers and new peers(10). However, the empirical evidence suggests that the positive association between sport and educational outcomes depends on race, gender, and type of sport(11).

In the USA, particularly, the evidence suggests positive associations between the practice of sports and White male students $(1,12)$. The evidence is mixed in the case of Black male students. Frequently, American football and basketball, classified as revenue sports, are linked to Black students and their participation in these sports is unrelated or negatively related to educational outcomes $(1,12-14)$.

The first studies on the nexus between sports and educational outcomes did not include female students, because of their low rates of participation in both sports and education. Nevertheless, in the last two decades girls have been considerably increasing their levels of participation, and the evidence suggests that they are able to obtain even more benefits from sports than boys due to higher levels of competitiveness stimulated by sports $(15,16)$. In the USA, the most recent findings suggest that sports are positively associated with college enrollment for White boys and girls, Black boys, and Latino boys and girls(17).

For the moment, it was not identified a study that examined the relationship between sports and educational outcomes in Russia. Therefore, the main goal of this research was to examine the associations of participation in sport activities in and out-of-school with school grades in Moscow and Saint Petersburg. These two cities were chosen because they concentrate the sport facilities of the country and because their levels of development and education quality differ from the rest of the country. Specifically, the research tested two hypotheses. First, the zero-sum hypothesis: sports negatively affect school grades, because they divert energies away from academic activities. Second, the developmental hypothesis: sports positively affect school grades, because they favor biological and psychosocial factors supporting academic activities.

\section{Methods}

\section{Study design and sample}

This was a longitudinal and observational study, which used data from round 19 (year 2010) to round 24 (year 2015) of the Russia Longitudinal Monitoring Survey (19). This survey aimed to study the effects of Russian reforms on the health and economic welfare of households and individuals. Five hundred and seventy-one children were examined. The ethical principles of research involving human beings were fully observed.

\section{Variables}

The dependent variable of this research (SCHOOL GRADES) was operationalized using the item "How would you estimate (his/ her) progress?", from the questionnaire for children, where parents or a responsible adult gave the answers. The response categories were: $1=$ Almost all the grades are five, $2=$ Basically all five and four, 3 = Basically all four, 4 = Basically all four and three, $5=$ Basically all three, $6=$ Basically all three and often two, $96=$ Marks are not given, $97=$ Doesn't know, $98=$ Refuses to answer. This variable was reversely coded the to be use as ordinal, so higher scores were reflective of higher educational progress. Options 96 to 98 were not included. Note that the grading (scholar years) system in Russia includes marks from 2 to 5 , where the minimal mark to pass is 3 .

The key independent variables on sport participation were operationalized using the item "Now I will list various kinds of physical activities and ask you to tell me in which of them (he/she) participates during class, and if so, for how many hours and minutes per week". The response categories are: 1) "Karate, judo, self-defense, wrestling, boxing, gymnastics", 2) "Active sports: badminton, tennis, soccer, basketball, volleyball, hockey, or swimming", 3) "Track and field, skiing, skating", and 4) "Other kinds of physical activity". With this information, were built four dummy variables on participation by type of sport: COMBAT, BALL, ATHLETIC, and OTHER SPORTS. In addition, were build four variables reporting 
the number of hours spent by type of sport AT SCHOOL.

Similarly, the item "I will list various physical activities and ask you to tell me in which (he/she) engages before or after classes, and for how many hours and minutes per week'. With this information, were built four dummy variables on participation and four variables on the number of hours spent by type of sport OUT-OF-SCHOOL.

Following previous research (20), socioeconomic status, public regular schools, health issues, age, and gender as control variables were used. Three items operationalized socioeconomic status (SES): "Does he/she have his/her personal (1) Tablet PC, (2) Mobile PC, notebook, laptop, netbook, and (3) Smartphone, Communicator, i-Phone". The response categories were $1=Y e s, 2=N o$, $6=$ used by several family members, $7=$ Doesn't know, $8=$ Refuse to answer. It was given 1 point for positive answers and 0.5 points for the use of the device by other family members. Then, the sum of the points gives an ordinal variable taking values from 0 to 3 .

It was built a dummy variable coded 1 for REGULAR SCHOOLS using the item "Is (he/she) studying in...?" with response categories 1 = Gymnasium or school with gymnasium classes, $2=$ School specialized in profile education of subjects, $3=$ Comprehensive college, lycee, $4=$ Nonresidency school, $5=$ Regular school, $6=$ Another type of school, $7=$ Doesn't know, $8=$ Refuse to answer.

The variable HEALTH ISSUES was operationalized using the item "How would you evaluate (his/her) health?" with response categories 1 = Very good, $2=$ Good, $3=$ Average-not good, not bad, $4=\mathrm{Bad}, 5=$ Very bad, $7=$ Doesn't know, $8=$ Refuse to answer. This variable so was reversely coded in order to higher scores reflect greater health.

Commonly, school students are 7 years old in 1st grade and 17 years old in the 11th grade (last year of post-secondary education). Therefore, the variable AGE was used as control for school years. It was also built dummy variables for Muscovites, male students, and for those students spending more than 10 hours per week on sports (HIGHPERFORMANCE ATHLETES).

\section{Statistical analysis}

First, correlation of dummy variables by type of sport and the corresponding variable on time spent by type of sport were examined with coefficients Person and Spearman.

Second, it was constructed regression equations, using panel data, the baseline specification was given by the following equation:

SCHOOL GRADES it $_{\text {. }}$

$$
\begin{aligned}
& =\text { TYPE OF SPORT AT SCHOOL' } \alpha_{i t-1} \\
& \text { + HOURS TYPE OF SPORT AT SCHOOL' } \gamma_{i t-1} \\
& \text { + TYPE OF SPORT OUT OF SCHOOL' } \delta_{i t-1} \\
& \text { + HOURS TYPE OF SPORT OUT OF SCHOOL' } \theta_{i t-1} \\
& + \text { CONTROL VARIABLES' } \rho_{i t}+\mu_{i}+u_{i t}
\end{aligned}
$$

To examine associations ordered probit regressions, with robust standard errors and random effects, for the estimation of the coefficients were used. The method allows control measures for time-invariant explanatory variables of school grades, including time-invariant variables affecting the selection effect into sports $(20,21)$. The variables on sport activities were included with one lag to account for endogeneity concerns.

Data were examined using the software Stata 13 and the confidence level for all analysis were of $95 \%$.

\section{Results}

Table 1 provides basic descriptive statistics of study variables and Table 2 presents the results of the regression analysis. The column 1 shows the estimated coefficients using the full sample, and columns 2 and 3 show the coefficients by subsamples of male and female students, respectively. Multicollinearity analysis, showed that there was not such effect.

Results (coefficients, column 1) suggest that sport activities at school are not associated with school grades (Table 2). Participation in other sports out-of-school was positive and statistically significant at the $10 \%$ level, which indicates that students practicing other sports have a higher probability of having obtained higher school grades. Conversely, time spent on other sports is negative and statistically significant at the 5\% level, which indicates that students spending more time on other sports reduce their chances of having obtained higher school grades. 
Number of hours dedicated to athletic sports out-of-school was positive and statistically significant at the 5\% level. However, this result is not robust because the dummy on participation in athletic sports was not statistically significant.

The control variables show the expected results. The proxy of SES and the ordinal variable on health issues were positive and statistically significant at the $5 \%$ level, that is, students with a higher socioeconomic status and greater health are more likely of having obtained higher school grades. On the contrary, age and gender were negative and statistically significant at the $1 \%$ level, that is, older and male students are more likely of having obtained lower school grades.

For girls, participation in other sports out-ofschool was positive and statistically significant at the $1 \%$ level and time spent on other sports out-of-school was negative and statistically significant at the 5\% level, which means that the practice of other sports increased probabilities for higher school grades, but spending too much time will reduce these probabilities.

For boys, participation in ball sports out-ofschool was positive and statistically significant at the 5\% level and time spent on ball sports was negative and statistically significant at the

Table 1 - Sample characteristics

\begin{tabular}{llllllll}
\hline Variable & Obs & $\begin{array}{l}\text { Mea } \\
\mathbf{n}\end{array}$ & SD & $\begin{array}{l}\text { Mi } \\
\mathbf{n}\end{array}$ & $\begin{array}{l}\text { Max } \\
\text { SCHOOL GRADES }\end{array}$ & $\begin{array}{l}\text { Mea } \\
\text { n }\end{array}$ & $\begin{array}{l}\text { Mean } \\
\text { Femal }\end{array}$ \\
\hline Sport activities in school & 152 & 4.33 & 1.1 & 1 & 6 & 4.10 & 4.58 \\
COMBAT SPORTS AT SCHOOL & 144 & 0.26 & 0.4 & 0 & 1 & 0.24 & 0.27 \\
BALL SPORTS AT SCHOOL & 144 & 0.59 & 0.4 & 0 & 1 & 0.63 & 0.54 \\
ATHLETIC SPORTS AT SCHOOL & 144 & 0.52 & 0.5 & 0 & 1 & 0.52 & 0.52 \\
OTHER SPORTS AT SCHOOL & 144 & 0.66 & 0.4 & 0 & 1 & 0.67 & 0.66 \\
HOURS COMBAT SPORTS AT SCHOOL & 141 & 0.20 & 0.5 & 0 & 10 & 0.20 & 0.20 \\
HOURS BALL SPORTS AT SCHOOL & 137 & 0.69 & 1.1 & 0 & 20 & 0.79 & 0.59 \\
HOURS ATHLETIC SPORTS AT & 138 & 0.53 & 0.7 & 0 & 8 & 0.52 & 0.53 \\
HOURS OTHER SPORTS AT SCHOOL & 133 & 0.79 & 1.0 & 0 & 20 & 0.75 & 0.83 \\
Sport activities out-of-school & & & & & & & \\
COMBAT SPORTS OUT SCHOOL & 856 & 0.23 & 0.4 & 0 & 1 & 0.28 & 0.17 \\
BALL SPORTS OUT SCHOOL & 856 & 0.49 & 0.5 & 0 & 1 & 0.59 & 0.38 \\
ATHLETIC SPORTS OUT SCHOOL & 856 & 0.28 & 0.4 & 0 & 1 & 0.25 & 0.31 \\
OTHER SPORTS OUT SCHOOL & 856 & 0.59 & 0.4 & 0 & 1 & 0.54 & 0.66 \\
HOURS COMBAT SPORTS OUT & 853 & 0.87 & 2.0 & 0 & 18 & 1.09 & 0.61 \\
HOURS BALL SPORTS OUT SCHOOL & 845 & 1.64 & 2.7 & 0 & 20.2 & 2.06 & 1.12 \\
HOURS ATHLETIC SPORTS OUT & 840 & 0.71 & 1.9 & 0 & 28 & 0.75 & 0.66 \\
HOURS OTHER SPORTS OUT SCHOOL & 822 & 2.21 & 3.1 & 0 & 21 & 1.97 & 2.49 \\
Control variables & & & & & & & \\
SES & 166 & 0.63 & 0.7 & 0 & 3 & 0.62 & 0.65 \\
HEALTH ISSUES & 165 & 3.76 & 0.5 & 2 & 5 & 3.77 & 3.76 \\
REGULAR SCHOOLS & 166 & 0.67 & 0.4 & 0 & 1 & 0.68 & 0.67 \\
MUSCOVITES & 166 & 0.87 & 0.3 & 0 & 1 & 0.88 & 0.85 \\
AGE & 166 & 10.44 & 2.6 & 6 & 19 & 10.64 & 10.23 \\
MALE & 166 & 0.51 & 0.5 & 0 & 1 & & \\
HIGH-PERFORMANCE ATHLETES & 166 & 0.03 & 0.1 & 0 & 1 & 0.04 & 0.03 \\
& 4 & & 7 & & & & \\
\hline Source: Own calculation & & & & & & &
\end{tabular}

Source: Own calculation 
Table 2 - Ordered probit regression coefficients for sport activities on school grades

\begin{tabular}{llll}
\hline Sport activities & All students & Male & Female \\
& \multicolumn{1}{c}{$(\mathbf{1})$} & $\mathbf{( 2 )}$ & $\mathbf{( 3 )}$ \\
\hline Sport activities in class at school & & & \\
COMBAT SPORTS AT SCHOOL & -0.18 & -0.05 & $-0.55^{*}$ \\
BALL SPORTS AT SCHOOL & -0.02 & -0.07 & 0.24 \\
ATHLETIC SPORTS AT SCHOOL & -0.26 & $-0.73^{* *}$ & 0.13 \\
OTHER SPORTS AT SCHOOL & 0.16 & 0.09 & 0.21 \\
HOURS COMBAT SPORTS AT SCHOOL & -0.15 & $-0.53^{* * *}$ & 0.14 \\
HOURS BALL SPORTS AT SCHOOL & 0.04 & 0.05 & -0.05 \\
HOURS ATHLETIC SPORTS AT SCHOOL & 0.16 & 0.31 & 0.18 \\
HOURS OTHER SPORTS AT SCHOOL & -0.09 & -0.09 & $-0.14^{*}$ \\
Sport activities before or after classes (out-of-school) & & & \\
COMBAT SPORTS OUT SCHOOL & 0.43 & $1.09^{* *}$ & 0.21 \\
BALL SPORTS OUT SCHOOL & 0.29 & $0.64^{* *}$ & -0.08 \\
ATHLETIC SPORTS OUT SCHOOL & -0.10 & 0.53 & -0.32 \\
OTHER SPORTS OUT SCHOOL & $0.35^{*}$ & 0.10 & $0.71^{* * *}$ \\
HOURS COMBAT SPORTS OUT SCHOOL & -0.01 & -0.14 & 0.0002 \\
HOURS BALL SPORTS OUT SCHOOL & -0.02 & $-0.08^{*}$ & $0.17^{*}$ \\
HOURS ATHLETIC SPORTS OUT SCHOOL & $0.08^{* *}$ & 0.04 & 0.09 \\
HOURS OTHER SPORTS OUT SCHOOL & $-0.07^{* *}$ & -0.07 & $-0.07^{* *}$ \\
Control variables & & & \\
SES & $0.24^{* *}$ & 0.18 & $0.36^{* *}$ \\
HEALTH ISSUES & $0.36^{* *}$ & $0.61 * * *$ & 0.19 \\
REGULAR SCHOOLS & -0.13 & 0.35 & $-0.56^{*}$ \\
MUSCOVITES & 0.25 & 0.62 & 0.06 \\
AGE & $-0.24^{* * *}$ & $-0.23^{* * *}$ & $-0.31^{* * *}$ \\
MALE & $-0.96^{* * *}$ & & \\
HIGH-PERFORMANCE ATHLETES & -0.004 & 0.46 & $-1.03^{* * *}$ \\
Observations & 458 & 245 & 213 \\
Pseudo R (a) & 0.72 & 0.71 & 0.75 \\
\hline (a) & & & \\
\hline
\end{tabular}

(a) The scale the log-likelihood value of the model to the log likelihood of the constant-only model. * significant at $10 \%$ level; ** significant at $5 \%$ level; *** significant at $1 \%$ level

$10 \%$ level, which means that practice of ball sports increases their probabilities of obtaining higher school grades, however, spend more hours on these sports reduces those probabilities.

Participation in combat sports and time spent on ball sports out-of-school, in the case of boys and girls, respectively, also show

significant coefficients, but they lack robustness.

There was statistical significance of the control variables according to gender. The socioeconomic status was statistically significant only for girls and health issues was statistically significant only for boys. In addition, for girls, regular public schools reduce their chances of obtaining higher school grades, and girls spending more than 10 hours on sports are less likely than other girls of obtaining higher school grades.

\section{Discussion}

In Russia, school students have options to practice sports at schools, mainly as part of physical education classes, yet these activities 
are practiced without seriousness and quality. The results of this research showed that sport activities at school are unrelated to school grades. These findings differ from several studies in the USA, where sports as extracurricular school activities presented significant associations with educational outcomes $(1,4,12,17)$. On the other hand, the practice of sports out-of-school (karate, judo, self-defense, wrestling, boxing, badminton, tennis, soccer, basketball, volleyball, hockey, gymnastics, and swimming) showed significant associations with school grades. The context in Russia sports are largely practiced in sport clubs or public sport services, the majority of them concentrated in Moscow and Saint Petersburg. In the case of boys, participation in ball sports is linked to higher school grades, yet those students spending more hours (over 10 hours per week) on ball sports will reduce their chances of obtaining higher school grades. This finding partially disagrees with previous studies in the United States of America (USA), where American football and basketball, classified as professional sports and related to majority of Black students, showed insignificant or negative relationships with educational outcomes $(1,13)$.

Age and gender were negative and statistically significant at the $1 \%$ level (Table 2 ), which means that older and male students are more likely of having obtained lower school grades. This gender gap, where girls outperform boys, has been already noted in the Russian literature and its explanation is still a question for future research $(20,22,23)$. Furthermore, here the results indicated differences in the effects of the practice of sports on school grades depending on gender.

The number of hours that girls spent on other sports out-of-school presented a negative and statistically significant coefficient at the 5\% level. In other words, particularly for girls, the sports practice out-of-school sports increases probabilities for obtaining higher school grades, yet female students spending more hours on these activities reduces those probabilities.

The findings on the present study supported the developmental hypothesis: sports positively affect school grades, because they favor biological and psychosocial factors supporting academic activities, but it was identified a threshold level. Sports practice favored school grades, however, spend more than 10 hours per week seems to affect negatively the educational performance. The effect can be observed in high school grades, among the high-performance athletes $(13,18)$.

\section{Strong points and limitations}

It is worth noticing that the main limitation of this study is the use of variables reported by parents, which could be biased. However, this limitation is controlled by the key advantage of this study, the use of panel data and econometric methods, controlling for timeinvariant explanatory variables of school grades.

\section{Conclusion}

Results of the present study, based on a sample of school students from Moscow and Saint Petersburg, showed that there is no evidence for the zero-sum hypothesis (claiming that sports divert students from academic activities). On the contrary, participation in sports contributes to encourage students to pursuit scholar objectives. Furthermore, sports practice at school is not linked to educational achievements, and this should be a result of the quality of physical education classes. Therefore, education policy makers should restore the worth of these classes, a demand that has been observed in the USA.

On the other hand, this research found evidence for the developmental hypothesis (claiming that sports encourage biological and psychosocial factors supporting educational outcomes). However, the findings of this research suggest that the key variable for observing benefits from sports on educational achievements is not the type of sport, revenue versus non-revenue sports, as pointed out in the American literature. Here, the key variable is time spent on sports. Parents and teachers should stimulate the practice of sports, but they should also moderate the time that their children spend on sports, because much time dedicated to sport activities will decrease their chances of obtaining higher school grades. 


\section{Acknowledgements}

The author would like to thank Juan Carlos Arismedi and Evgeniya Guseva for their helpful and constructive comments that greatly contributed to improving the final version of this article.

\section{Conflict of interests}

There is no conflict of interest in this study.

\section{Funding statement}

There was no funding for this study.

\section{References}

1. Eitle TM, Eitle DJ. Race, Cultural Capital, and the Educational Effects of Participation in Sports. Sociology of Education. [Online] 2002;75(2): 123-146. Available from: doi: $10.2307 / 3090288$

2. Lamborn SD, Brown BB, Mounts NS, Steinberg L. Putting school in perspective: The influence of family, peers, extracurricular participation, and parttimework on academic engagement. In: Newmann FM (ed.) Student engagement and achievement in American secondary schools. New York: Teachers College Press; 1992. p. 153-181.

3. Eccles JS, Barber BL. Student Council, Volunteering, Basketball, or Marching Band: What Kind of Extracurricular Involvement Matters? Journal of Adolescent Research. [Online] 1999;14(1): 10-43. Available from: doi:10.1177/0743558499141003

4. Bailey R. Sport, physical activity and educational achievement - towards an explanatory model. Sport in Society. [Online] 2016;(July): 1-21. Available from: doi:10.1080/17430437.2016.1207756

5. Park RJ. Play, Games and Cognitive Development: Late Nineteenth-Century and Early Twentieth-Century Physicians, Neurologists, Psychologists and Others Already Knew What Researchers Are Proclaiming Today. The International Journal of the History of Sport. [Online] 2014;31(9): 1012-1032. Available from: doi:10.1080/09523367.2013.877448
6. Bird KS, Tripney J, Newman M. The educational impacts of young people's participation in organised sport: a systematic review. Journal of Children's Services. [Online] 2013;8(4): 264-275. Available from: doi:10.1108/JCS-04-20130014

7. Van Deventer K. Educational worth of physical education and sport participation: A review. South African Journal for Research in Sport, Physical Education and Recreation. 2014;36(3): 183-200.

8. Lunn PD, Kelly E. Participation in school sport and post-school pathways: Evidence from Ireland. National Institute Economic Review. [Online] 2015;232(1): 51-66. Available from: doi:10.1177/002795011523200106

9. Barron JM, Ewing BT, Waddell GR. The effects of high school athletic participation on education and labor market outcomes. Review of Economics and Statistics. [Online] 2000;82(3): 409-421. Available from: doi:10.1162/003465300558902

10. DeMeulenaere E. Playing the game: Sports as a force for promoting improved academic performance. Journal of Cultural Diversity. 2010;17(4): 127-135.

11. Hwang S, Feltz DL, Kietzmann LA, Diemer MA. Sport Involvement and Educational Outcomes of High School Students: A Longitudinal Study. Youth \& Society. [Online] 2016;48(6): 763-785. Available from: doi:10.1177/0044118X13513479

12. Mackin RS, Walther CS. Race, sport and social mobility: Horatio Alger in short pants? International Review for the Sociology of Sport. [Online] 2011;47(6): 670-689. Available from: doi:10.1177/1012690211429212

13. Rettig J, Hu S. College Sport Participation and Student Educational Experiences and Selected College Outcomes. Journal of College Student Development. [Online] 2016;57(4): 428-446. Available from: doi:10.1353/csd.2016.0054

14. Harris PC. The Sports Participation Effect on Educational Attainment of Black Males. 
Education and Urban Society. [Online] 2014;46(5): 507-521. Available from: doi:10.1177/0013124512446219

15. Troutman KP, Dufur MJ. From High School Jocks to College Grads: Assessing the Long-Term Effects of High School Sport Participation on Females' Educational Attainment. Youth \& Society. [Online] 2007;38(4): 443-462. Available from: doi:10.1177/0044118X06290651

16. Pfeifer C, Cornelißen T. The impact of participation in sports on educational attainment - New evidence from Germany. Economics of Education Review. [Online] 2010;29(1): 94-103. Available from:

doi:https://doi.org/10.1016/j.econedurev.20 09.04 .002

17. Shifrer D, Pearson J, Muller C, Wilkinson L. College-Going Benefits of High School Sports Participation: Race and Gender Differences Over Three Decades. Youth \& Society. [Online] 2015;47(3): 295-318. Available doi:10.1177/0044118X12461656

18. Gayles GJ, Hu S. The influence of student engagment and sport participation on college outcomes among division I student athletes. The Journal of Higher Education. [Online] 2009;80(3): 315-333. Available from: doi:10.1353/jhe.0.0051

19. RLMS-HSE. Russian Longitudinal Monitoring Survey. [Online] Russian Longitudinal Monitoring Survey. Available from: https://www.hse.ru/en/rlms/ [Accessed: 20th March 2017]

20. Tovar-García ED. Migration background and educational achievements in Russia. Migraciones Internacionales. [Online] 2017;9(1): 69-93. Available from: doi:http://dx.doi.org/10.17428/rmi.v9i32.8 89

21. Baltagi B. Econometric analysis of panel data. Third edit. Chichester, West Sussex, England: JohnWiley \& Sons; 2005. 302 p.

22. Tovar-García ED. Determinants of Educational Outcomes in Yaroslavl, Russia. Revista Electrónica de Investigación Educativa. [Online] 2013;15(2): 100-113.
Available from: http://www.scielo.org.mx/scielo.php?script $=$ sci_arttext\&pid $=$ S1607-

40412013000200007\&lng=es\&nrm=iso

23. Tovar-García ED. Determinants of educational outcomes: Analysis of the Republic of Tatarstan. Communist and Post-Communist Studies. [Online] 2014;47(1): 39-47. Available from: doi:10.1016/j.postcomstud.2014.01.001. 